\title{
Effect of Polysaccharide-Based Film on Morphometric of Rat liver
}

\author{
Gulsara Rysmuhambetova Irina Ziruk*, and Marina Copcecchi \\ Federal State-Owned Publicly-Funded Institution Of Higher Education Saratov SAU named after N.I. \\ Vavilov, Russia, 410012, Saratov, 1 Teatralnaya Ploshchad
}

\begin{abstract}
In the modern world, most manufacturers try to use film coatings that have the following properties: manufacturability, safety, biodegradability, and economic availability. The provided materials present the results of studying the effect of a film based on polysaccharides on the morphology of rat liver. An experiment was carried out on laboratory animals, in the course of its carrying out the morphological structure of the rat liver was studied, which showed that use of films based on polysaccharides is safe for laboratory animals.
\end{abstract}

\section{Introduction}

Many scientists are trying to create improved packaging materials for food storage, allowing to extend shelf life, as well as preserve and improve the quality of products and goods. The created food films or coatings are thin layers of materials that manufacturers apply to manufactured products to preserve nutrients and increase shelf life. Use of these films contributes to enrichment of food products with various vitamins, minerals, complexes of microelements, due to the ability to retain various compounds among themselves $[1,5,7,10-12]$.

Xanthan gum is a food supplement E415 in the form of a polysaccharide obtained by fermentation using a bacterium of the genus Xanthomonas campestris. The gum is most commonly used as a gelling agent, thickener, stabilizer or film coating in food systems [79].

The liver plays an essential role in the metabolism of naturally occurring substances in the body, as well as during various experiments. Therefore, if harmful substances enter the body, their effect will be displayed on the indicated organ. The liver belongs to the congestive gland of the digestive system of the body, which performs a number of important functions, one of which is detoxification, i.e. neutralization of incoming toxic substances $[2,3]$.

\section{Methods}

\footnotetext{
* Corresponding author: iziruk@yandex.ru
} 
In the conditions of the veterinary clinic of the Saratov State Agrarian University, the authors carried out a scientific experiment on laboratory animals - white rats, weighing 175 - $180 \mathrm{~g}$, which received food films based on polysaccharides as part of the feed. In the course of the study, the safety of cling film based on polysaccharides was determined for the general condition of the organism of laboratory animals, which were received in the form of xanthan gum. Clinically healthy laboratory animals - rats, 10 males with a live weight of 175-180 g were studied under experimental conditions. The studied animals were kept according to generally accepted methods. Before the experiment, the rats were kept in quarantine for a period of 21 days [4]. After quarantine, the rats were divided into two groups (five individuals in each): group 1 - control, 2 - experimental. All conducted experimental studies in the experiment with rats were carried out in compliance with the requirements of Federal Law of January 01, 1997 "On Protection of Animals ...", as well as the provisions of the European Convention for the Protection of Animals (Strasbourg, March 18, 1986) were respected.

The rats of the control group received food according to the generally accepted recipe of complete feed for rats [4] in short-term experiments. The rats of the experimental group were injected with xanthan gum in the form of food films as part of the diet. On the 30th day of the experiment, euthanasia was performed using gas anesthesia (Isoflurane), and pieces of liver were taken from the rats. From pieces of liver $1 \times 1 \mathrm{~cm}$ in size, histological sections were made on a freezing microtome. The prepared sections with a thickness of 10 $\mu \mathrm{m}$ were stained according to the standard technique, hematoxylin - with eosin. They were studied under a microscope with a lens magnification of $* 10$ and an eyepiece at $* 4,10,40$, 100.

Throughout the experiment, no external signs of intoxication were observed in the studied animals of all groups. The rats were active, no disturbances in reactions to external stimuli were observed, the body temperature remained within the limits of their age, physiological gradations. During the entire period of the experiment, no death was noted in the control and experimental groups of laboratory animals.

\section{Results}

The digestive system occupies the most important and rather important niche in the absorption of essential nutrients. The degree of digestion, its level of compliance with the necessary needs of the body is recorded by factors such as the physiological development of the body, the metabolism taking place in it, as well as the immune reactivity of the body as a whole. Disorders of various functional abilities of the digestive tract of the body are interrelated with postnatal morphogenesis, both at the cellular and tissue stages.

When studying sections of the liver of rats of the control group using a microscope, it was noted that the hepatic lobules are well expressed, tightly adjoined to each other, their interlobular tissue was poorly differentiated, the beams - passing from the wall of the lobule to the central sinusoid, are expressed from clear individual cells - hepatocytes. Sinusoids are elongated, their boundaries are not clear. The central vessels of the lobules are large; in a few of them, a minimum number of blood cells was observed. Kupffer cells or amoeboid endothelial cells were found in sinusoids between hepatocytes (Fig. 1). Hepatocytes in animals of the experimental groups are of irregular, round, multifaceted shape, there are single binuclear cells, some of them consist of nuclei of different sizes. The nucleoli are clearly visible, single nuclei with two or more nucleoli are visible. In the rats of the control group, decomplexation of the beam structures of the liver lobules was revealed; their triads were indistinct. Liver parenchyma in rats of experimental groups was observed in the form of well-developed multifaceted lobules, which are delimited by minimal interlobular connective tissue. The beams of the lobules, consisting of multifaceted or cubic 
hepatocytes, are located radially. Interlobular triads (vein, artery, bile duct) were clearly visualized.

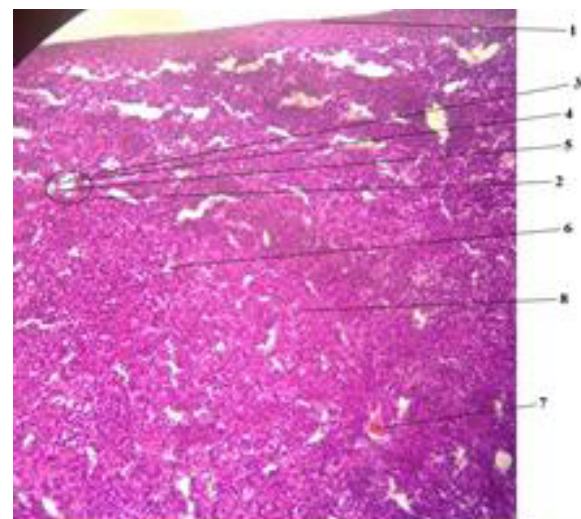

A - control group

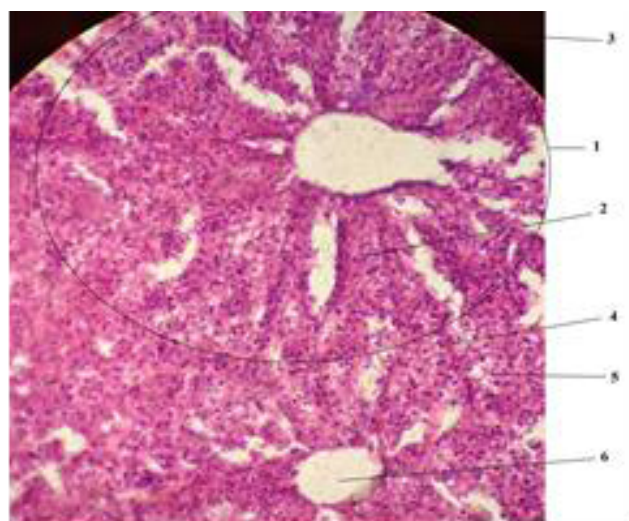

B - experimental group

Fig. 1. Rat liver. 1 - capsule, 2 - triad, 3 - vein, 4 - artery, 5 - bile duct, 6 - sinusoidal capillaries, 7 - blood cells, 8 - hepatocytes. Env. G.E., magn. 40.

In rats fed with food films based on polysaccharides, a minimal overflow of blood in the central vessels was observed, where the minimum number of blood cells was also observed, the walls of the veins had clear, well-contoured membranes, which indicates rather intensive blood circulation in the liver of the experimental groups of rats than those, from control.

The integrity of the walls of the central vessels of the liver of laboratory animals of control and the structure of the walls of the triads are changed, the perisinusoidal space occupies a much larger part, in comparison with the liver of experimental groups of laboratory animals.

We also measured the radius of the liver lobules and calculated their average diameter. It was calculated using a lens and a 60-division eyepiece ruler. In rats of the control group, the radius of the liver lobules averaged $52.2 \pm 0.05 \mu \mathrm{m}$. In rats of the experimental group (which received a dietary supplement - xanthan in the form of a film) $72.1 \pm 0.025 \mu \mathrm{m}$. According to the data obtained, it follows that the studied indicator in rats of the experimental group exceeded the analogs of the control by $19.9 \mu \mathrm{m}$.

\section{Discussion}

According to the results of the experiment, it shall be concluded that food film based on polysaccharides in the form of xanthan gum does not pose a danger when eaten by laboratory animals, and does not adversely affect the structure and structure of the liver, therefore, it is biologically safe. Radial fluctuations revealed in the hepatic lobules of the studied organ of the experimental group of rats indicate a rather intense blood circulation, when compared with animals of the control group, and an increase in their various metabolic processes [13-14].

In rats whose diet was supplemented with the studied supplement, in the form of a film based on polysaccharides, an excess of the diameter of the lobules was observed, the walls of the central veins were clearer, rather well contoured, and the central veins were minimally filled with blood. The integrity of the vessel walls and the structure of interlobular triads, both in the experimental and control groups, were not violated. 


\section{Conclusion}

Studying the general morphological structure of the liver of experimental rats, it shall be concluded that the addition to the diets of experimental animals of feed with a food additive in the form of a film based on polysaccharides does not have a negative or negative effect on the studied parameters, but somewhat increases the course of metabolic processes in the body of experimental rats, which indicates on the biological safety of the use of products in the composition of food film based on polysaccharides for laboratory animals.

\section{References}

1. S.V. Dezhatkina, SH.R. Zyalalov, A.Z. Muhitov, M.E. Dezhatkin, N.V. SHaronina, V.V. Ahmetova, Agrarnaya nauka, 2 (2021)

2. I.V. Ziruk, Veterinarnyj vrach, 1 (2013)

3. I.V. Ziruk, Rossijskij veterinarnyj zhurnal, 4 (2013)

4. I.V. Petruhin, N.I. Petruhin, Kormlenie domashnih i dekorativnyh zhivotnyh (1992)

5. I.V. Fayustova, T.K. Kalenik, I.A. Suprunova, Materialy VIII studentcheskoj mezhdunarodnoj zaochnoj nauchno-prakticheskoj konferencii nauchnoe soobshchestvo studentov XXI stoletiya (Novosibirsk, 2013)

6. S.Yu. Makarova, G.E. Rysmukhambetova, I.V. Ziruk, Sbornik statej Vserossijskoj nauchno-prakticheskoj konferencii (Saratov, 2018)

7. Yu.V. Ushakova, G.E. Rysmukhambetova, I.V. Ziruk, V.V. Frolov, K.A. Grandonyan, E3S Web of Conferences. Ser. «Development of the Agro-lndustrial Complex in the Context of Robotization and Digitalization of Production in Russia and Abroad» (2020)

8. H. Karimi-Maleh, S. Ranjbari, B. Tanhaei, A. Ayati, Y. Orooji, M. Alizadeh, Environmental Research, 195 (2021)

9. D. Kashyap, H. S. Tuli, M. B. Yerer, A. Sharma, K. Sak, S. Srivastava, Seminars in Cancer Biology, 69 (2021)

10. K. Kumar, S. Srivastav, V. S. Sharanagat, Ultrasonics Sonochemistry, 70 (2021)

11. M. Nasrollahzadeh, M. Sajjadi, S. Iravani, R.S. Varma, Carbohydrate Polymers, 251 (2021)

12. B. P. M. Ngou, H. Ahn, P. Ding, J. D. G. Jones, Nature, 592 (2021)

13. C. Xu, Y. Wang, C. Liu, C. Zhang, W. Han, X. Hong, Science Advances, 7,1 (2021)

14. M. Zubair, P. M. Adnan Ramzani, B. Rasool, M. A. Khan, M., Akhtar, Journal of Environmental Management, 284 (2021) 